\title{
A Study on the Standardization of Sugar-preserved Prunus mume Manufactured in Ha-Dong
}

Yu-Jin Ko, Hyo-Hyeong Lee, Eun-Ja Kim, Hui-Hun Kim, Yong-Hwi Son, Jin-Yong Kim, Sang-Dong Kang, Ji-Hye $\mathrm{An}^{1}$, Wan-Su Lee ${ }^{2}$ and Chung-Ho Ryu*

Division of Applied Life Science (BK21 program), Institute of Agriculture and Life Science, Gyeongsang National University, Jinju 660-701, Korea ${ }^{1}$ Department of Food Science and Technology, Gyeongsang National University. Jinju 660-701, Korea

${ }^{2}$ Division of Future Agriculture, Hadong Agriculture Technology and Extension Center, Hadong-Gun, Gyeongsangnam-Do, Korea

Received December 24, 2009 /Accepted January 25, 2010

\begin{abstract}
Prunus mume is rich in organic acid, and excels in antioxidant activity. However, development of processed foods using Prunus mume is very limited, and characteristics of its products are different according to the region they are processed in. In this study, we collected 13 kinds of sugar-preserved Prunus mume home-made products in Hadong, and investigated their physical and manufacturing characteristics to select a superior product. 5 kinds of sugar-preserved Prunus mume products were selected according to results of sensory evaluation, and the overall acceptability of product No.13 was superior. Moisture contents of the 5 samples ranged from $45.2 \sim 53.3 \%$, and $\mathrm{pH}$ and acidity showed similar values at about 2.8 and $0.4 \%$, respectively. Sugar content of product No.13 were slightly lower than other products. Crude protein and lipid contents were similar at about 0.4 and $0.8 \%$, respectively. Hardness value of product No.13, selected by its texture in sensory evaluation, was higher than others. The main components of organic acids were oxalic, malic, citric and fumaric acid, and citric acid content occupied more than $60 \%$ of total organic acid content. Also, the main components of free sugar were glucose and fructose.
\end{abstract}

Key words : Sugar-preserved, Prunus mume

\section{서 론}

매실은 장미과 매화나무의 핵과류로서 강한 알칼리성 과 일이며 한국, 중국 및 일본의 온난한 지역에 분포하는 동양 고유종이다[11]. 현재 수확되고 있는 매실은 $60 \%$ 가 음료, $28 \%$ 주류, 나머지는 식초를 비롯한 기타 가공식품 제조에 사용되 고 있다[3]. 또한 건위, 주독, 해독 및 구충제 등 한약재로 일부 이용되어 왔으며, 이질균, 포도상구균, 장티푸스에 대한 살균 효과와 설사, 변비, 위산과다, 위경련 등 소화기계 질병 및 호 흡기계 질병에 대한 예방 등이 전해지고 있다[10]. 그러나 매 실은 신맛이 강하여 생으로 섭취하기 힘들고 수확 후 급속한 후숙 작용으로 인해 청과 유통이 어렵다. 따라서 수확직후 곧 바로 가공하는데 대부분 매실주나 엑기스 제조에 이용되고 있어 생산량에 비해 가공 규모와 다양성이 적고 품질이 균일 하지 못하여 상품화가 아직 미흡한 수준이다[9]. 지금까지 보 고된 매실의 국내 연구는 이[9] 등의 매실의 부산물을 이용한 신소재 개발 및 기초자료 연구나 황[4] 등의 매실의 항산화성, 강[6] 등의 매실의 주요 향기성분 등으로 생매실의 부가가치 를 상승시키기 위한 가공식품 개발에 관한 연구는 전무한 실

\footnotetext{
*Corresponding author

Tel : +82-55-751-5482, Fax : +82-55-753-4630

E-mail : ryu@gnu.ac.kr
}

정이다.

매실을 이용한 가공식품으로는 매실주, 매실주스, 매실 당 절임, 매실잼, 매실엑기스 및 매실식초 등이 있으며 이 중 매실 당절임은 매실에 올리고당이나 자당을 혼합하여 숙성시킨 식 품으로 광양, 하동 지역 등에서 많이 제조되고 있다[12]. 매실 당절임 제품은 농가 단위의 소규모로 제조되고 있으며 체계화 되지 못한 제조법으로 품질에 의한 수익의 편차가 크다. 최근 매실의 부가가치를 상승시키기 위한 매실 당절임에 관한 연구 는 김 등[7]의 열처리를 통한 매실 당절임 식품의 저장성 향상 과 김[8]의 매실 당절임의 저장성 향상 연구가 보고되어 있으 나 제품의 향미, 산미, 조직감 및 저장성 등을 체계적으로 분석 평가하여 균일한 품질관리가 될 수 있는 요소를 설정하는 기 초연구가 절실하다. 이에 본 연구에서는 경남 하동지역에서 생산되는 매실 당절임 제품을 수집하여 우수한 제품을 선별하 고 제조 특성을 분석하여 지역 상품화를 위한 고품질의 매실 당절임 제조의 표준화 방안을 모색하였다.

\section{재료 및 방법}

\section{실험재료}

본 실험에 사용한 매실 당절임 제품은 2008년 경남 하동군 지역에서 재배된 매실을 이용하여 제조한 것으로 농가단위의 
소규모로 시판중인 것을 구입하여 매실 당절임 외부의 수분을 제거하여 시료로 사용하였다.

\section{우수한 매실 당절임 제품의 선별}

수집한 매실 당절임 제품을 사전에 관능평가에 관한 내용을 충분히 이해를 시킨 20 30세의 남, 여 30명을 패널로 선정하 여 외관, 조직감, 신맛, 단맛, 전체적인 기호도를 5점 평점법으 로 평가하여 가장 좋다 5 , 가장 나쁘다 1 로 점수를 표시하였으 며 높은 점수를 얻은 5 개의 제품을 선별하여 품질특성을 조사 하였다.

\section{$\mathrm{pH}$, 산도 및 당도}

매실 당절임 제품의 $\mathrm{pH}$, 산도 및 당도는 각각 마쇄한 시료 $1.0 \mathrm{~g}$ 에 증류수 $9 \mathrm{ml}$ 을 첨가한 후 여과(Whatman No. 2)하여 사용하였다. 매실 당절임 제품의 $\mathrm{pH}$ 는 $\mathrm{pH}$ meter $(420 \mathrm{~A}$, Orion Inc., U.S.A.)로 측정하였으며 산도는 여액 $1 \mathrm{ml}$ 에 $1 \%$ phenolphthalein용액 2 3방울을 가하여 $0.1 \mathrm{~N} \mathrm{NaOH}$ 를 표준 용액으로 중화 적정한 후 구연산으로 환산하여 \%로 나타내었 다. 또한 hand refractometer (KRÜSS, Germany)를 이용하여 당도를 측정하였다.

\section{수분 함량 측정}

매실 당절임 제품의 수분은 마쇄한 시료 $5.0 \mathrm{~g}$ 을 적외선 수분측정기(FD-600, Kett)로 $40 \mathrm{~min}$ 동안 측정하였다.

\section{조단백질 함량 측정}

매실 당절임 제품의 조단백질 함량은 A.O.A.C [1]의 kjel$\mathrm{dahl}$ 법을 이용하여 측정하였다. 시료 $1.0 \mathrm{~g}$ 을 정확히 칭량하 여 약포지에 싸서 분해 플라스크에 넣고 분해촉진제 약 1.0 $\mathrm{g}$ 과 $\mathrm{H}_{2} \mathrm{SO}_{4} 30 \mathrm{ml}$ 을 첨가한 후 가열분해 장치에서 가열하였다. 시료가 검은색에서 청색으로 변한 후 $30 \mathrm{~min}$ 간 더 가열하였 다. 가열분해가 끝나면 냉각한 후 강산을 희석시키기 위해 증 류수 $4 \mathrm{ml}$ 을 가한 후 $32 \% \mathrm{NaOH}$ 로 중화하였다. $30 \mathrm{ml} \mathrm{H} \mathrm{BO}_{3}$ 에 지시약(0.4 g Brom cresol green; $0.2 \mathrm{~g}$ Methyl red; 100 $\mathrm{ml}$ Ethanol)을 1 2방울 떨어뜨린 후 auto kjeldahl 장치로 단 백질을 추출하였다. 회수액을 $0.1 \mathrm{~N} \mathrm{HCl}$ 으로 적정한 후 조단 백질 함량을 구하였다.

\section{조지방 함량 측정}

매실 당절임 제품의 조지방 함량은 A.O.A.C [1]의 Soxhlet 법을 이용하여 측정하였다. 시료를 정확히 칭량하여 원통여지 에 넣고 시료 위를 탈지면으로 가볍게 막고 추출관 속에 넣었 다. 항량을 미리 구한 수기에 ether $100 \mathrm{ml}$ 을 넣은 후 추출관과 냉각관을 연결하여 8 16 hr 동안 지방을 추출하였다. 수기를 분리하여 감압 농축기로 ether를 회수하고 $105^{\circ} \mathrm{C}$ 에서 $1 \mathrm{hr}$ 건 조 후 항량을 측정하여 조지방 함량을 구하였다.

\section{색도 측정}

매실 당절임 제품의 색도는 $1.0 \times 1.0 \times 1.0 \mathrm{~cm}^{3}$ 길이로 잘라서 직경 $3.0 \mathrm{~cm}$, 높이 $1.0 \mathrm{~cm}$ 의 용기에 담아 색차계(Minolta CT-300, Japan)를 사용하여 측정하였으며, 그 값을 Hunter's $\mathrm{L}$ (명도), a (적색도), b (황색도)로 표시하였다.

\section{조직감 측정}

매실 당절임 제품의 조직감을 측정하기 위하여 $5.0 \times 5.0 \times 5.0$ $\mathrm{mm}^{3}$ 길이로 잘라서 Texture analyser (TAXT express, MHK Co., Korea)로 다음과 같은 조건에서 기계적 경도(Hardness) 를 10회 측정하여 평균값을 나타내었다. Cylinsrical plunger는 직경 $12 \mathrm{~mm}$ 로, crosshead speed는 $1 \mathrm{~mm} / \mathrm{s}$ 로, load cell은 2 $\mathrm{kg}$ 으로, chart speed는 $10 \mathrm{~mm} / \mathrm{min}$ 으로 하였다.

\section{유기산 함량 측정}

매실 당절임 제품의 유기산 함량은 차[2]의 방법을 변형하 여 마쇄한 시료 $5.0 \mathrm{~g}$ 에 증류수 $45 \mathrm{ml}$ 을 가하여 $25^{\circ} \mathrm{C}$ 에서 2 $\mathrm{hr}$ 환류 추출한 후 여과(Whatman No.2, Japan)하여 $60 \%$ perchloric acid $50 \mu \mathrm{l}$ 를 첨가하여 단백질을 침전시킨 다음 0.22 $\mu \mathrm{m}$ membrane filter (Millipore, USA)로 여과하였다. Sep-pak $\mathrm{C}_{18}$ (Waters Co. Milford, Massachusetts USA)로 여액에서의 색소 및 단백질 성분을 제거한 후 HPLC로 분석하였다. 유기 산의 분석조건은 detector: Water $301, \mathrm{UV} /$ visible $(214 \mathrm{~nm})$, column: LUNA $5 \mu \mathrm{C}_{18}(100 \times 4.6 \mathrm{~mm})$, flow rate: $1 \mathrm{ml} / \mathrm{min}$, mobile phase: $0.02 \mathrm{M} \mathrm{KH}_{2} \mathrm{PO}_{4}$, injection vol.: $20 \mu \mathrm{l}$ 로 하였다.

\section{유리당 함량 측정}

매실 당절임 제품의 유리당 함량은 차[2]의 방법을 변형하 여 마쇄한 시료 $5.0 \mathrm{~g}$ 에 $80 \%$ ethanol $45 \mathrm{ml}$ 을 첨가하여 $80^{\circ} \mathrm{C}$ 에 서 2시간 환류 추출한 후 여과(Whatman No. 2, Japan)하여 감압 농축하였다. 이를 $0.22 \mu \mathrm{m}$ membrane filter (Millipore)로 여과하였으며 Sep-pak $\mathrm{C}_{18}$ (Waters Co. Milford, Massachusetts USA)로 여액에서의 색소 및 단백질 성분을 제거한 후 HPLC 로 분석한다. 분석조건은 detector: Water $301, \mathrm{UV} /$ visible (214 nm), column: carbohydrate analysis $(100 \times 4.6 \mathrm{~mm})$, flow rate: $1 \mathrm{ml} / \mathrm{min}$, mobile phase: acetonitrile-water $(80: 20 \mathrm{v} / \mathrm{v})$, injection vol.: $20 \mu \mathrm{l}$ 를 사용한다.

\section{결과 및 고찰}

\section{하동 매실 당절임 제품의 선별}

가내 수공업 형태로 제조되고 있는 하동 지역의 매실 당절 임 제품은 제조자별로 품질의 차가 심해 소비층의 확대 및 지역 특산물로서의 산업화에 문제점이 지적되고 있다. 이에 본 연구에서는 하동 지역의 제조되고 있는 매실 당절임 제품 을 수집하여 품질특성을 중심으로 매실 당절임 제품 13 종의 
Table 1. The sensory evaluation of sugar-preserved Prunus mume products

\begin{tabular}{|c|c|c|c|c|c|c|c|c|c|c|c|c|c|}
\hline Product No. & 1 & 2 & 3 & 4 & 5 & 6 & 7 & 8 & 9 & 10 & 11 & 12 & 13 \\
\hline & & & & & & & & & & & & & 4 \\
\hline & & & & & & & & & & & & & \\
\hline & & & & & & & & & & & & & \\
\hline & $2.6 \pm 0.1$ & $2.8 \pm 0.1$ & $2.3 \pm 0.2$ & $2.7 \pm 0.2$ & $2.7 \pm 0.2$ & & & & & & & & $4.1 \pm 0.1$ \\
\hline Overall acceptability & $3.0 \pm 0.2$ & $3.2 \pm 0.1$ & $2.1 \pm 0.1$ & $2.7 \pm 0.1$ & $2.6 \pm 0.3$ & $2.7 \pm 0.2$ & $2.3 \pm 0.1$ & $2.2 \pm 0.2$ & $3.0 \pm 0.1$ & $3.7 \pm 0.2$ & $3.8 \pm 0.1$ & $4.0 \pm 0.2$ & $4.3 \pm 0.1$ \\
\hline
\end{tabular}

Table 2. Proximate composition of sugar-preserved Prunus mume products

\begin{tabular}{|c|c|c|c|c|c|}
\hline Product No. & 2 & 10 & 11 & 12 & 13 \\
\hline Moisture (\%) & $45.20 \pm 0.13$ & $53.00 \pm 0.21$ & $47.80 \pm 0.13$ & $50.00 \pm 0.21$ & $51.40 \pm 0.12$ \\
\hline $\mathrm{pH}$ & $2.89 \pm 0.11$ & $2.67 \pm 0.19$ & $2.85 \pm 0.12$ & $2.85 \pm 0.18$ & $2.87 \pm 0.12$ \\
\hline Sugar (Brix) & $54.00 \pm 0.14$ & $54.00 \pm 0.12$ & $55.00 \pm 0.14$ & $55.00 \pm 0.12$ & $50.00 \pm 0.14$ \\
\hline Acidity $(\%)$ & $0.30 \pm 0.01$ & $0.30 \pm 0.08$ & $0.45 \pm 0.10$ & $0.45 \pm 0.02$ & $0.30 \pm 0.06$ \\
\hline Crudeprotein (\%) & $0.34 \pm 0.13$ & $0.41 \pm 0.01$ & $0.32 \pm 0.10$ & $0.44 \pm 0.08$ & $0.45 \pm 0.06$ \\
\hline Crude lipid (\%) & $0.88 \pm 0.04$ & $0.72 \pm 0.08$ & $0.81 \pm 0.04$ & $0.74 \pm 0.11$ & $0.79 \pm 0.05$ \\
\hline
\end{tabular}

관능평가 결과를 Table 1에 나타내었다. 13종의 매실 당절임 제품에서 선명한 청색을 지니고 당의 삼투현상에 의한 찌그러 짐이 없는 외관과 조직이 단단하여 아삭아삭한 조직감을 가진 13 번 제품이 가장 우수한 것으로 나타났다. 또한 11번 제품에 서 가장 적당한 신맛을 가지고 있는 것으로 나타났으며 13 번 제품에서 한국인에게 거부감을 주지 않는 단맛의 정도가 가장 적당한 것으로 나타났다. 소비자들이 가장 거부감 없이 쉽게 접할 수 있는 매실 당절임 제품으로서 전체적인 기호도가 13 번 제품이 가장 우수한 것으로 나타났다.

\section{매실 당절임 제품의 일반성분 분석}

관능평가 결과 기호성이 우수한 5종의 매실 당절임 제품의 일반성분을 분석한 결과를 Table 2에 나타내었다. 하동지역에 서 가공되는 매실 당절임 제품의 수분 함량은 $45.2 \sim 53.3 \%$ 로 나타났으며 강[5]등의 매실 과육의 수분함량 $89.9 \%$ 에 비해 매 우 낮은 값을 나타내었다. 이는 매실 당절임 제품의 숙성과정 중 당의 삼투 현상으로 매실내의 수분이 빠져 나오면서 감소 된 것으로 생각된다. 매실 당절임 제품의 $\mathrm{pH}$ 는 $2.7 \sim 2.9$ 이며 산도는 $0.3 \sim 0.45 \%$ 로 실험구간에 큰 차이는 보이지 않았다. 또한 당도는 13 번 제품에서 $50.6{ }^{\circ} \mathrm{Brix}$ 로 가장 낮게 나타났으며 이외의 제품에서는 약 $55{ }^{\circ} \mathrm{Brix}$ 내외로 유사하게 나타났다. 따

Table 3. Color values of sugar-preserved Prunus mume products

\begin{tabular}{cccc}
\hline \multirow{3}{*}{ Product No. Color values } \\
\cline { 2 - 4 } & L value & a value & b value \\
\hline 2 & $36.63 \pm 1.21$ & $-0.46 \pm 0.34$ & $15.14 \pm 1.25$ \\
10 & $35.12 \pm 0.96$ & $-1.03 \pm 0.84$ & $15.14 \pm 0.61$ \\
11 & $39.34 \pm 1.46$ & $-1.03 \pm 1.24$ & $26.40 \pm 1.72$ \\
12 & $52.07 \pm 2.63$ & $-3.74 \pm 0.96$ & $32.55 \pm 2.54$ \\
13 & $52.11 \pm 2.21$ & $-3.45 \pm 0.10$ & $30.88 \pm 3.11$ \\
\hline
\end{tabular}

라서 관능평가 결과와 비교했을 때 당과 산의 함량이 다소 낮은 제품의 기호도가 높을 것으로 생각된다.

매실 당절임 제품의 조단백질 함량과 조지방 함량은 각각 $0.32 \sim 0.45 \%, 0.72 \sim 0.88 \%$ 로 실험구간에 큰 차이는 보이지 않 았다. 이[9] 등의 당절임 매실과육즙에서 조단백질과 조지방 함량은 각각 $0.13,0.19 \%$ 로 본 연구결과에 비해 다소 낮게 나타 났는데 이는 당절임 매실 원료인 과육 착즙 시 용출되지 않고 펄프층에 잔존하는 양만큼의 손실에 기인하는 것으로 추측된 다. 또한 황[4]등의 신선한 매실 과육의 조단백질과 조지방 함 량은 각각 $0.45,0.19 \%$ 로 보고하였으며 강 $[6]$ 등의 조단백질, 조 지방 함량은 각각 $0.92,2.88 \%$ 로 보고하여 본 연구결과와 다소 차이를 보였다. 이는 매실의 품종, 환경(기후)조건 및 채취시 기, 담금 후의 발효 미생물 증식에 따른 균체 성분의 혼입 등 다양한 내·외적인 요소들에 의한 것으로 생각된다.

\section{매실 당절임 제품의 색도}

관능평가 결과 기호도가 우수한 5종의 매실 당절임 제품의 색도를 측정한 결과를 Table 3에 나타내었다. 매실 당절임 제 품 12,13 번의 $\mathrm{L}$ 값과 $\mathrm{b}$ 값은 2,10 및 11 번 제품에 비해 높게 나타났으며 a값은 2, 10 및 11번에 비해 다소 낮게 나타났다. 따라서 12,13 번 제품은 나머지 제품에 비해 밝은 색을 나타내 었으며 적색보다는 황색과 청색에 가깝게 나타났다. 따라서 관능평가의 색상관찰 결과와 비교했을 때 밝으면서 황색과 청색에 가까운 제품을 소비자가 선호하는 것으로 생각된다.

\section{매실 당절임 제품의 조직감}

매실 당절임 제품의 조직감을 비교하기 위하여 기계적인 경도 값을 측정한 결과를 Fig. 1에 나타내었다. 5종의 우수한 매실 당절임 제품의 경도는 $887.7 \sim 1116.1 \mathrm{~g} / \mathrm{cm}^{2}$ 로 관능평가 결과 조직감이 우수했던 13 번 제품의 경도가 가장 높았고 다 
Table 4. Organic acid contents of sugar-preserved Prunus mume products

\begin{tabular}{|c|c|c|c|c|c|c|c|c|c|c|}
\hline \multirow{2}{*}{ Product No. } & \multicolumn{2}{|l|}{2} & \multicolumn{2}{|l|}{10} & \multicolumn{2}{|l|}{11} & \multicolumn{2}{|l|}{12} & \multicolumn{2}{|l|}{13} \\
\hline & Contents(mg\%) & $\%$ & Contents(mg\%) & $\%$ & Contents(mg\%) & $\%$ & Contents(mg $\%)$ & $\%$ & Contents(mg\%) & $\%$ \\
\hline Oxalic acid & $1.0 \pm 0.1$ & 1.1 & $1.0 \pm 0.1$ & 0.9 & $1.5 \pm 0.1$ & 2.0 & $2.1 \pm 0.1$ & 2.0 & $1.1 \pm 0.1$ & 0.8 \\
\hline Malic acid & $30.8 \pm 0.8$ & 34.9 & $26.6 \pm 1.6$ & 24.4 & $25.3 \pm 2.5$ & 34.3 & $32.8 \pm 3.6$ & 31.9 & $40.3 \pm 2.1$ & 29.1 \\
\hline Citric acid & $56.5 \pm 2.4$ & 63.9 & $81.5 \pm 3.1$ & 74.7 & $47.0 \pm 4.2$ & 63.7 & $68.0 \pm 3.8$ & 66.1 & $97.7 \pm 4.1$ & 70.1 \\
\hline Fumaric acid & $0.1 \pm 0.1$ & 0.1 & - & - & - & - & - & - & - & - \\
\hline Total & $88.4 \pm 0.4$ & 100 & $109.0 \pm 3.1$ & 100 & $73.8 \pm 5.2$ & 100 & $102.9 \pm 1.2$ & 100 & $138.5 \pm 3.9$ & 100 \\
\hline
\end{tabular}

Table 5. Free sugar contents of sugar-preserved Prunus mume products

\begin{tabular}{|c|c|c|c|c|c|c|c|c|c|c|}
\hline \multirow{2}{*}{ Product No. } & \multicolumn{2}{|l|}{2} & \multicolumn{2}{|l|}{10} & \multicolumn{2}{|l|}{11} & \multicolumn{2}{|l|}{12} & \multicolumn{2}{|l|}{13} \\
\hline & Contents(mg\%) & $\%$ & Contents(mg\%) & $\%$ & Contents (mg\%) & $\%$ & Contents(mg\%) & $\%$ & Contents $(\mathrm{mg} \%)$ & $\%$ \\
\hline Glucose & $2,650.6 \pm 63.6$ & 67.0 & $2,890.0 \pm 22.4$ & 70.1 & $2,860.4 \pm 52.1$ & 69.1 & $2,511.6 \pm 78.7$ & 65.3 & $2,121.7 \pm 64.2$ & 67.7 \\
\hline Fructose & $1,231.1 \pm 79.2$ & 31.0 & $1,107.5 \pm 48.6$ & 27.7 & $1,251.1 \pm 74.4$ & 30.2 & $1,112.4 \pm 112.1$ & 28.9 & $952.8 \pm 33.6$ & 30.5 \\
\hline Rhamnose & $72.8 \pm 4.5$ & 2.0 & $85.8 \pm 8.4$ & 2.2 & $33.2 \pm 4.6$ & 0.8 & $.10 \pm 0.9$ & 1.5 & $12.6 \pm 3.1$ & 0.5 \\
\hline Sucrose & - & - & - & - & - & - & $161.3 \pm 10.1$ & 4.2 & $42.1 \pm 6.8$ & 1.3 \\
\hline Total & $3,952.5 \pm 79.1$ & 100 & $4,083.2 \pm 88.3$ & 100 & $4,144.7 \pm 45.2$ & 100 & $3,846.3 \pm 110.8$ & 100 & $3,129.2 \pm 67.8$ & 100 \\
\hline
\end{tabular}

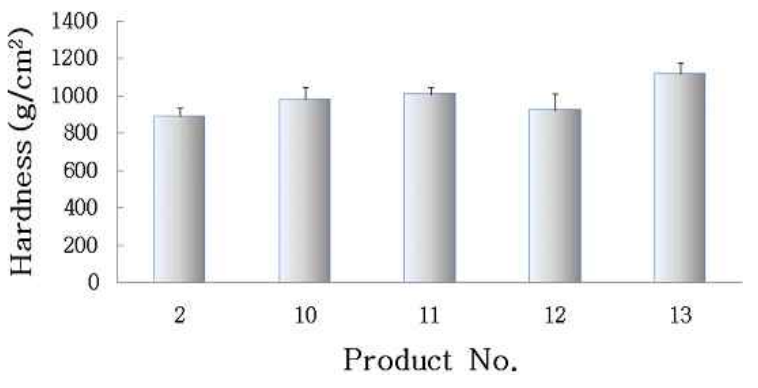

Fig. 1. Texture of sugar-preserved Prunus mume products.

른 4종의 매실 당절임 제품의 경도는 유사했다. 따라서 매실 당절임 제품의 조직이 단단할수록 기호도가 높은 점으로 미루 어 제조 및 저장 중 연화를 억제하여 아삭아삭한 물성을 유지 하는 것이 중요한 요소임을 확인하였다.

\section{매실 당절임 제품의 유기산 함량}

매실에 풍부하게 함유되어 있고 저장 - 숙성 과정 중에 어우 러져서 상큼한 신맛을 내는 것으로 추측되는 유기산 함량을 분석한 결과를 Table 4에 나타내었다. 모든 매실 당절임 구에 서 수산, 사과산, 구연산 및 푸마르산이 대표적인 유기산으로 검출되었으며 이 중 구연산의 함량이 가장 높았다. 모든 실험 구에서 구연산이 전체 유기산 함량의 $60 \%$ 이상을 차지하였다.
관능평가 결과 전체적인 기호도가 가장 우수했던 13 번 제품 은 사과산과 구연산 함량이 다른 구에 비해 월등히 높았다. 매실 당절임 제품중의 유기산 함량과 비율이 제품의 기호도에 많은 영향을 미칠 것으로 사료된다.

정 [5] 등은 매실의 주요 유기산은 수산, 주석산, 사과산, 구 연산, 숙신산 등이며 과실이 미숙상태에서는 사과산의 함량이 높고 완숙 후에는 구연산의 함량이 높다고 보고하여 본 연구 결과와 유사하게 나타났다.

\section{매실 당절임 제품의 유리당 함량}

매실 당절임 제품의 주요 유리당은 glucose, fructose, sucrose 및 rhamnose가 검출되었다(Table 5). 매실 당절임 제품 에 함유되어 있는 유리당 중 glucose의 함량은 전체 유리당 함량에 $65 \%$ 이상으로 매우 높게 나타났으며 fructose 함량은 약 $30 \%$ 내외로 나타났다. 차[2] 등은 매실의 성숙기간에 따른 유리당 함량을 알아본 결과 성숙 초기에는 glucose 함량이 가 장 높았다가 성숙기간이 증가함에 따라 감소하는 것으로 보고 하였으며 강[6] 등은 매실 과육에 함유되어 있는 유리당 중 glucose의 함량이 가장 높은 것으로 보고하여 본 연구 결과와 유사하게 나타났다. 이는 본 연구에 사용된 매실은 숙성 초기 청매를 사용하였기 때문에 glucose 함량이 가장 높게 나타난 것으로 생각되며 강[6] 등의 연구 결과에 비해 유리당 함량이

Table 6. Manufacturing characteristics of sugar-preserved Prunus mume products

\begin{tabular}{lccccc}
\hline \multicolumn{1}{c}{ Product No. } & 2 & 10 & 11 & 12 & 13 \\
\hline$P$. mume flesh : Sucrose & $5.0: 5.0$ & $5.0: 5.0$ & $5.0: 5.0$ & $5.0: 5.0$ & $5.5: 4.5$ \\
Species & Native species & Native species & Native species & Nam-go & Back-ga-ha \\
Cultivated region & Ha-dong & Ha-dong & Ha-dong & Gwang-yang & Ha-dong \\
Aging periods & 8 month & 8 month & 8 month & 7 month & 7 month \\
\hline
\end{tabular}


높게 나타난 것은 매실 당절임 제조 과정 중에 사용된 설탕이 매실 내로 유입되었기 때문으로 사료된다. 또한 차등 매실 과 육에 함유되어 있는 주요 유리당은 glucose, sorbitol, maltose 및 fructose 등이며 강[6] 등은 glucose, fructose, sorbitol 및 mannitol로 보고하여 품종에 따라 다소 차이가 있는 것으로 생각된다.

매실 당절임 제품의 전체 유리당 함량은 3,129.2 4,144.7 $\mathrm{mg}$ \%로 나타났으며 13 번 제품에서 가장 낮게 나타났다. 이는 매실 당절임 제품의 당도 결과와 유사한 경향을 나타내었으며 12 번, 13 번 제품의 sucrose 함유량이 다른 구에 비해 다소 높게 나타났다.

\section{우수한 매실 당절임 제품의 제조상 특성조사}

하동지역에서 제조된 2008년 매실 당절임 제품 13 종의 관능 검사 결과 기호도가 우수한 5 종의 제품을 선발하여 각 제품의 품질특성을 조사하였다(Table 6). 2, 10 및 11번 제품은 하동지 역에서 생산되는 품종을 알 수 없는 재래종이었고 12 번 제품 은 남고(南高), 13 번 제품은 백가하(百加賀)를 원료로 사용하 여 제조한 것이었다.

종실을 제거한 매실 과육과 자당의 배합비율을 조사한 결과 $2,10,11$ 및 12 번 제품은 $5: 5$ (매실 : 자당 $\mathrm{w} / \mathrm{w}$ )의 동일한 양을 혼합하여 제조하였으며 13 번 제품은 $5.5: 4.5$ 로 자당을 다소 적게 첨가하여 제조하였다. 또한 5종 모두 약 7 개월 이상 $5^{\circ} \mathrm{C}$ 의 저온에서 숙성시킨 것으로 조사되었고 이 중 13 번 제품 의 품질이 가장 우수하게 나타났다.

이상의 결과를 토대로 본 연구에서는 하동지역에서 주로 생산되고 관능검사 결과 조직감이 가장 우수한 백가하 품종을 매실 당절임 제조용 품종으로 적합함을 판단하였고 과육과 자당을 $5.5: 4.5$ 비율로 배합하여 제조하는 것이 가장 우수한 제품을 생산할 수 있을 것으로 생각된다.

\section{감사의 글}

본 연구는 하동군에서 지원한 지역농산물 가공기술 표준화 지원 사업 연구용역(계약번호: 20090231742-00) 연구비 지원과 BK21 program 지원으로 수행되었기에 이에 감사드립니다.

\section{References}

1. A.O.A.C. 1990. pp. 876, Official methods analysis $15^{\text {th }}$, Association of Official Analytical Chemists. Washington D.D.

2. Cha, H. S., J. B. Hwang, J. S. Park, Y. K. Park, and J. S. Cho. 1999. Changes in chemical composition of Mume (Prunus mume Sieb. et Zucc) fruits during maturation. Korean J. Postharvest Sci. Technol. 6, 481-487.

3. Ha, M. H., W. P. Park, S. C. Lee, and S. H. Choi. 2005. Organic acids and volatile compounds isolated from Prunus mume extract. Korean J. Food Preserv. 12, 195-198.

4. Hwang, J. Y., J. W. Ham, and S. H. Nam. 2004. The antioxidant activity of Maesil (Prunus mume). Korean J. Food Sci. Technol. 36, 461-464.

5. Jung, B. M., N. D. Kang, M. Kil, and K. U. Song. 2007. Comparison of fruit qualities before and after maturity in Japanese Apricot cultivars. pp. 99, 25th, Korean J. Hort. Sci. Technol.

6. Kang, M. Y., Y. H. Jung, and J. B. Eun. 1999. Physical and chemical characteristics of flesh and pomace of Japanese Apricots (Prunus mume Sieb. et Zucc). Koran J. Food Sci. Technol. 31, 1434-1439.

7. Kim, S. B., T. Y. Kim, H. R. Kim, and H. K. Jun. 2004. A study on improved storeage of sugaring Prunus mume using the thermal anneal. Korean J. Community Living Sci. 15, 266-268.

8. Kim, S. B. 2005. A study on improved storeage of sugaring Prunus mume. Rural Resource and Survey 104, 9-12.

9. Lee, E. H., O. J. Choi, and K. H. Shim. 2004. Properties on the quality characteristics of muffin added with sugaring Ume puree. J. Korean Soc. Food Sci. Nutr. 9, 58-65.

10. Lee, S. L., K. N. Park, Y. S. Im, and W. J. Choi. 2002. Effects of Prunus mume Sie. extract on growth of lactic acid bacteria isolated from kimchi and preservation of kimchi. Korean J. Food Preserv. 9, 292-297.

11. Seo, K. S., C. K. Huh, and Y. D. Kim. 2008. Changes of biologically active components in Prunus mume fruit. Korean J. Food Preserv. 15, 169-273.

12. Son, Y. A. 1994. A study on flavor of Prunus mume. pp. 48, Yeungnam University Press. 


\section{초록 : 하동지역 매실 당절임의 표준화 방안 연구}

고유진 · 이효형 · 김은자 · 김희훈 · 손용휘 · 김진용 · 강상동 · 안지혜 ${ }^{1} \cdot$ 이완수 ${ }^{2}$ 류충호*

(경상대학교 응용생명과학부(BK 21 프로그램) · 농업생명과학연구원, ${ }^{1}$ 경상대학교 농생명학부, ${ }^{2}$ 경상남도 하동군 농업기술센터)

본 연구에서는 하동 지역에서 제조되고 있는 13종의 매실 당절임 제품을 수집하여 외관, 조직감, 신맛, 단맛 및 전체적인 기호도 등 관능평가 결과 우수한 제품 5 종을 선별하여 이화학적 및 제조 특성을 조사하였다. 5 종의 매실 당절임 제품의 수분함량은 45.2 53.3\%였으며 $\mathrm{pH}$ 는 약 2.8 내외로 모든 실험구가 유사하게 나타났다. 산도 는 $0.4 \%$ 내외로 모든 당절임 제품에서 유사하였고 당도는 13 번 제품이 다른 실험구들에 비해 다소 낮게 나타나 당과 산의 함량이 낮은 제품의 관능적 기호도가 높을 것으로 생각된다. 또한 조단백질, 조지방 함량도 모든 실험 구들에서 각각 약 $0.4,0.8 \%$ 내외로 유사하게 나타났다. 관능평가시 조직감이 가장 우수하다고 선별된 13 번 제품 의 기계적 경도 값이 다른 구에 비해 높게 나타났으며 색도는 밝은 색에 황색과 청색에 가까운 제품이 소비자의 관능에 우수할 것으로 생각된다. 5종의 우수한 매실 당절임 제품의 주요 유기산은 수산, 사과산, 구연산 및 푸마 르산으로 나타났으며 구연산 함량은 전체 유기산 함량의 $60 \%$ 이상 수준이었다. 또한 주요 유리당은 glucose, fructose, rhamnose 및 sucrose로 나타났으며 glucose 함량은 전체 유리당 함량에 $65 \%$ 이상 검출되어 당도 결과 와 유사한 경향을 나타내었다. 하동지역에서 제조되고 있는 매실 당절임 제품 13 종의 관능검사 결과 기호도가 우수한 5종의 제품 중 2, 10 및 11번은 하동지역에서 재배되는 품종을 알 수 없는 재래종이었고 12번 제품은 남고 (南高), 13번 제품은 백가하(百加賀) 품종으로 제조된 것이었다. 또한 매실 과육과 자당의 배합비율은 $5.5: 4.5$ 로 제조된 13 번 제품을 제외하고 4 종의 제품에서 동일한 비율로 제조하였으며 7 개월 이상 저온에서 숙성시킨 것으 로 조사되었다. 따라서 하동지역에서 주로 생산되고 지역적 상품화가 될 수 있는 매실 당절임을 제조하기 위해서 는 백가하 품종으로 과육과 자당을 $5.5: 4.5$ 비율로 배합하여 $5^{\circ} \mathrm{C}$ 의 저온에서 약 7 개월 이상 숙성시켜 제조하는 것이 가장 적합 할 것으로 생각된다. 